International Conference on Research in Management \& Economics

Serbia | Belgrade | December 15-17, 2018

\title{
Demand of SMEs for Bank Financing: The Case of Turkey
}

\author{
Aysa Ipek Erdogan \\ Boğaziçi University, İstanbul, Turkey, aysa.erdogan@boun.edu.tr
}

\begin{abstract}
Although SMEs rely on bank financing for growth and survival in developed and developing countries, they encounter difficulties in access to bank loans. Banks do not prefer to provide loans to SMEs because of insufficient accounting records and high probability of failure. This paper investigates the demand of Turkish SMEs for bank financing. We find that the majority of the SMEs did not apply for bank financing in the last three years and in the last year. However, we show that the demand of SMEs for bank loans would increase with lower interest rates and lower collateral requirements. Nearly all of the managers of the SMEs in the sample that did not apply for a loan in the last three years declared that not making an application is not caused by the fear of rejection. Therefore, we can suggest that borrower discouragement is not the cause of absence of demand for bank financing for Turkish SMEs.
\end{abstract}

Keywords: SMEs, Bank loans, financial constraints 